\title{
SACRED Thresholds
}

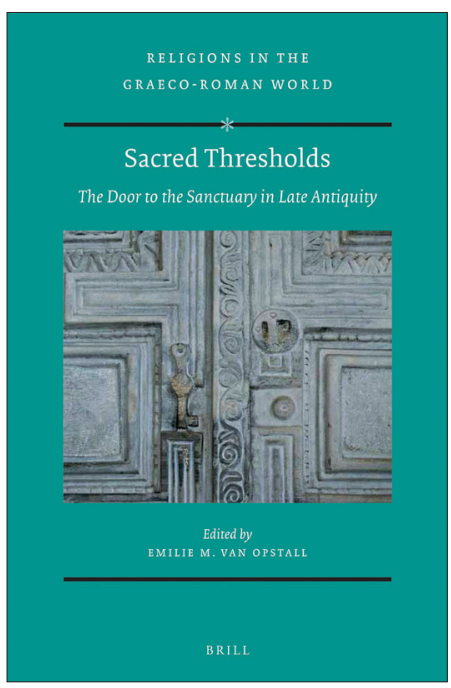

VAN OPSTALL, EMILIE M. (ed.) (2018). Sacred Thresholds. The Door to the Sanctuary in Late Antiquity. Religions in the Graeco-Roman World, 185. Leiden and Boston: Brill. 376 pp., 252,00€ [ISBN 9789-0043-6859-0].

\section{BEATRICE CASEAU \\ UNIVERSITÉ PARIS-SORBONNE \\ BEATRICE.CASEAU@SORBONNE-UNIVERSITE.FR}

THIS BOOK PUBLISHES THE PAPERS GIVEN AT A CONFERENCE ORGANIZED in 2015 by S. de Blaauw and Emilie Van Opstall at the Vrije University in Amsterdam, which gathered specialists from different fields: archaeology, history, art history, theology, Classics and Byzantine studies. The book is however edited by Emilie M. Van Opstall. All of the articles are written in English, but their authors come from different scholarly cultures and countries: Italy, Holland, France, Hungary, Finland, Great Britain. They were at the time of publication at different stages in their career from postdoctoral positions to emeriti. Most of them are classicists, some are art historians or historians. The book contains 50 figures: color and b/w photographs and floor plans to help readers visualize space or details. The volume is carefully edited, and the editor connects the different articles in footnotes. Each article has a separate bibliography. 
The book is focused on doors and all of the articles but one study thresholds as a place of transition and focus on liminality. The subtitle of the book limits the topic to a period in time and a type of doors: The door to the sanctuary in Late Antiquity. This is slightly misleading: some of the articles cover another period of time. The chronological span of the book extends from the $7^{\text {th }}$ cent. BCE to the $8^{\text {th }}$ cent. CE. Sanctuary is used either in a "broad sense for a pagan sacred place of cult, as well as in the narrow sense for the Christian inner sanctuary" (p. 3). Most of the articles deal with Christian buildings and Late antique or early Byzantine sources, but one is concerned by Neoplatonic philosophers and two by ancient Greek buildings. Geographically the book is mostly centered on the Eastern Mediterranean, but two articles deal with Rome and one studies Nola and Merovingian Gaul.

The introduction by E. Van Opstall details the theoretical frame which centers on the notion of liminality and calls on the "spatial turn" in the Humanities and the field of emotions and cognitive psychology. She then explains how the book is organized in four sections of different sizes: 1) experiencing sacred thresholds, 2) Symbolism and Allegory of Sanctuary doors, 3) messages in stone and 4) the presence of the divine.

The first section has the following articles:

1. Emilie M. van Opstall, On the Threshold: Paul the Silentiary's Ekphrasis of Hagia Sophia.

2. Juliette Day, Entering the Baptistery: Spatial, Identity and Salvific Transitions in Fourth- and Fifth-Century Baptismal Liturgies.

3. Christian Boudignon, From Taboo to Icon: The Entrance to and the Exit from the Church in the First Three Greek Liturgical Commentaries (ca 500-730 CE).

4. Ildikó Csepregi, Bonus Intro, Melior Exi ! 'Inside' and 'Outside' at Greek Incubation Sanctuaries.

The second section, Symbolism and Allegory of Sanctuary doors, has three articles:

5. Lucia M. Tissi, Sanctuary Doors, Vestibules and Adyta in the Works of Neoplatonic Philosophers.

6. Sible L. de Blaauw, The Paradise of Saint Peter's.

7. Roald Dijkstra, Imagining the Entrance to the Afterlife: Peter as the Gatekeeper of Heaven in Early Christianity.

The third section, "messages in stone", deals with inscriptions around doors, has also three articles: 
8. Evelien J. J. Roels, The Queen of Inscriptions Contextualised: The Presence of Civic Inscriptions in the pronaos of Ancient Temples in Hellenistic and Roman Asia Minor (Fourth Century BCE-Second Century CE).

9. Gianfranco Agosti, Verses De Limine and In Limine: Displaying Greek paideia at the Entrance of Early Christian Churches.

10. Gaëlle Herbert de la Portbarré-Viard, The Door to the Sanctuary from Paulinus of Nola to Gregory of Tours: Enduring Characteristics and Evolutions from the Theodosian to the Merovingian Period.

The last section, "the presence of the divine", has two:

11. Christina G. Williamson, Filters of Light: Greek Temple Doors as Portals of Epiphany.

12. Brooke Shilling, The Other Door to the Sanctuary: The Apse and Divine Entry in the Early Byzantine Church.

In the first article, E. Van Opstall studies Paul the silentiary description of the Hagia Sophia, which takes the visitor on a virtual sensory tour of the $6^{\text {th }}$ cent. cathedral. The article pays special attention to the different doors, some of which are no longer visible. The article is presented as a case study on the different functions of doors and a study of continuities with the pagan past.

In her article, "Entering the Baptistery: Spatial, Identity and Salvific Transitions in Fourth- and Fifth-Century Baptismal Liturgies", Juliette Day studies baptismal liturgies at Milan and Jerusalem, revealed by liturgical commentaries: Ambrose of Milan, De Sacramentis and De Mysteriis and Cyril of Jerusalem Mystagogical catecheses. The author is aware of the discussion around the authenticity and dates of these treatises. She grants both treatises to Ambrose and dates them to the 390s, but grants the catecheses to John, bishop of Jerusalem after Cyril. There is no consensus on either attribution. Here again as in the first article, the emphasis in on experiencing the building and the rite taking place within, pointing to the different layout of the entrance door: one baptistery stands alone, the other is located within the cathedral complex. The role of the door in opening a new identity to the catechumens is emphasized in both cases. The mystagogical catecheses explain the experience afterwards and ask the newly baptized to rememorate their feelings. These were emotionally charged rituals.

Christian Boudignon starts with a citation of Ambrose of Milan but his focus is on Byzantine liturgical commentaries by Pseudo-Dionysius, Maximus the Confessor and Germanus of Constantinople. With this article, the book enters into the world of medieval Byzantine liturgy with its two entrances, the first one with the clergy and the second with the holy gifts, after the exit of catechumens, energumens and 
penitents. The article is centered on the circulation of clerics and lay people and the different symbolic significance of their passing through doors. The article shows that although still mentioned, the dismissal of catechumens is no longer relevant in the $8^{\text {th }}$ cent. and the main event is now the Great entrance, that is the procession with the holy gifts through the doors of the church and into the sanctuary.

With Ildikó Csepregi's article, Bonus Intro, Melior Exi! "Inside" and "Outside" at Greek Incubation Sanctuaries, we travel through time from Antiquity to Late antiquity. The article focuses on the ritual of incubation, which implies sleeping inside a healing sanctuary. The article presents how much the Christian incubation rituals owes to its Greek predecessor. Two case studies are studied: incubation at the Epidaurus temple of Asclepius and a visit to the church of saint Artemios in Constantinople, and other healing sanctuaries known to us by "thaumata", miracle stories. Doors give access to healing and the article focuses on how they are used to regulate entrance by visitors and exclude some (women in one instance).

The second section of the book deals with the symbolic meaning of doors.

With Lucia M. Tissi's article, Sanctuary Doors, Vestibules and Adyta in the Works of Neoplatonic Philosophers, we leave the world of Christian buildings to go back to temples. The article focuses on the intellectual and spiritual experience involved in passing through the doors of sanctuaries. The authors studied Neoplatonic philosophers who lived during Late antiquity. They use spaces and doors to describe the self-transformation process. Doors of knowledge have an initiatory significance; they allow the soul to travel away from ignorance into the adyton of the Good.

The two following articles lead us to Rome around the atrium of Saint Peter's church for Sible L. de Blaauw's article and around the figure of Peter keeper of keys for Roald Dijkstra's article. Both articles are in the section on symbolic meaning, because they both deal with entering into Paradise: physically for the church atrium was called the "Paradise" in the Liber pontificalis ecclesiae romanae, and imaginatively for Peter was depicted as gatekeeper to Paradise.

Part three gathers articles studying inscriptions around doorways. They are organized chronologically, one deals with a large selection of different civic inscriptions located in the pronaos of Asia Minor Hellenistic and Roman temples, from the $4^{\text {th }}$ cent. $\mathrm{BCE}$ to the $2^{\text {nd }}$ cent. CE, another with $4^{\text {th }}$ and $5^{\text {th }}$ cent. CE metrical inscriptions of Greek classicizing poetry or verses of psalms present on lintels, thresholds and mosaic floors of churches in Constantinople and Jerash, and the last article leads us to explore the symbolic role of church doors as a transition between human space and divine residence at Nola in the time of Paulinus, and to the more troubled and violent world of Gregory of Tours, where doors of sanctuaries could be forced. 
The last section of the book, entitled "Divine presence" is the less convincing for the theme of the book. The first article of this section at least studies temple doors. We go back to ancient Greece in that article which focuses on door as "jewels of temple architecture" and objects of prestige, fit for cult images within the walls of the temple. Their opening created an epiphany of the divine in rituals. Although the article is very well written and convincing, it lacks some conceptual link with Late Antiquity and what became of such rituals. The use of curtains could have been invoked, or the presence of icons on iconostasis facing the doors of later Byzantine churches. The last article, by Brooke Shilling, although entitled "the other door to the sanctuary" is about apses in early Byzantine churches. It comments on different choices of images for the apse: Christ floating above the Eucharist celebrated on the altar or the Virgin Mary. With examples taken from churches in Cyprus, the article argues that the presence of the Theotokos in apses should be connected to liturgical poetry describing her as the ladder, the bridge, the gate of salvation, the "door of hallowed mystery".

As usual with collected essays, it is very difficult to keep one thematic line and explore it in different regions or religious cultures. The selection reflects the limits of a conference. For a book on Late antiquity expanding into the $7^{\text {th }}-8^{\text {th }}$ cent. and mainly centered on the Eastern part of the Mediterranean, one would wish to have an article on the door of the Dome of the Rock or the Mosque in Damascus. The link between antiquity and the Byzantine period is very clearly spelled out in the article on incubation practices, less so in the other articles starting in the Antique world. These reservations aside, this is an extremely interesting collection of essays that can appeal to art historians, philologists and scholars in religious studies. It fulfills its promise to consider doors and thresholds from different points of view, revealing one important aspect in the dynamics of sacred spaces from ancient Greek temples to early Byzantine churches. 